\title{
The research on joint venture between China and Kazakhstan in
}

\author{
energy and transport cooperation \\ Garafutdinova Daniya, Yongjian Zong* \\ Nanjing University of Science and Technology, School of Economics and Management, \\ China \\ * Corresponding author: Yongjian Zong, Professor, zongyongjian@sina.com
}

\begin{abstract}
The purpose of this empirical analysis is to investigate, based on gravity model, FDI flow from China to Kazakhstan during 2008-2016 year and NLS model. The estimation is controlled for the importance of gravity variables (GDP, per capita GDP, Distance, Common border and Common organization the latest variables are dummy). The results suggest that gross products of host regions and source countries and dummy variables as common border and being the members of the same organization are positively related to the number of joint ventures in a particular Kazakhstan's region.
\end{abstract}

Key words: research and development, foreign direct investment, joint venture, gravity model, Chinese direct investment.

\section{Introduction}

Practical cooperation between China and Kazakhstan is deepening constantly. China is one of the most important trade and investment partner of Kazakhstan. The total investment of China in Kazakhstan's economy exceeded \$ 42.8 billion, while lending is a total of more than $\$ 50$ billion. For example, in 2008 the gross inflow of foreign direct investment from China to Kazakhstan was amounted to 7,932 million dollars, and in 2016 to 9,609 million dollars.

FDI takes a number of forms: MNEs building production facilities in countries other than their own country, expanding or reinvesting in such facilities, engaging in cross border mergers and acquisitions (M\&As), and establishing international strategic alliances such as joint ventures (JVs) with companies from a different country. The geographical restructuring of the world's automotive industry has taken place through the process of FDI undertaken by the industry's major corporations. The number of JVs in the Republic of Kazakhstan has increased several hundred times over the past 20 year. 
The parties have identified 51 projects of cooperation in the sphere of production capacities, which will cover strategic sectors of bilateral cooperation in energy and transport sectors. 100 million tons of oil were delivered to China via the pipeline China - Kazakhstan and 183 billion cubic meters of gas also were delivered via the pipeline China — Kazakhstan. Cooperation on new energy sources such as nuclear energy, wind energy have developed actively. In 2016 over 1200 freight trains between China - Europe transit through Kazakhstan were driven, the volume of rail traffic reached 8.2 million tons.

So if the JV is one of the best option how to realize the FDI why it is not so common? What kind of risks it have?

The institutional theory focuses on the relationship the organization has with its surrounding environment. Both the firms' institutional internal environment and the host country's external environment affect firms' decisions of ownership ${ }^{1}$. Also was introduced a framework to explain the impact of institutional theory on the entry decisions of international retailers, which differ from that of manufacturers².

The question how internal and external institutions correspond with one another to explain entry mode choices (institutional duality) ${ }^{2,3}$. However, only a few studies empirically investigate internal and external institution, and these studies usually consider institutions to be direct antecedents. For example, such studies consider entry mode choice in one country (e.g., past entry modes and cultural distance as well as regulatory institutions) and in different countries (e.g., internal cognitive structures and regulative risk and cultural distance) as well as entry mode change (internal isomorphic pressures and governmental regulations) ${ }^{4}$.

To sum up, most of the current researches are mainly focused on establishing of Joint Venture mostly concetrated in the theoretical questions such as choosing parther, ownership. There are few studies on creating Joint Venture between two countries in general, and no deep analysis of narrow field of cooperation which is also a new idea for this paper.

\section{Experimental (mathematical formulas, tables and equations)}

\subsection{Empirical model}

Gravity model of inward Foreign Direct Investment (FDI) is specified to determine the sources of uneven distribution of FDI between China and Kazakhstan. The most simple form of the gravity model of bilateral trade is:

$$
F_{i j}=A \frac{Y_{i} Y_{j}}{D_{i j}}
$$

where: 
$>$ Fij represents the flows (i.e. migration, tourism, trade, foreign direct investment) between the home country i and the host country j;

$>$ A is a constant of proportionality.;

> Yi and Yj: are the relevant economic sizes (GDP, GDP per capita, Populatin) of countries $(\mathrm{i}, \mathrm{j})$;

> Dij: is the distance between countries' capitals or economic/financial centre ${ }^{5}$.

Equation (1) states that bilateral flows between country i and country $\mathrm{j}$ are directly related to the product of the countries' GDP (Yi and Yj) and inversely related to their distance (Dij). This formula firstly was applied to analyse international trade flows in 1962. Later, in 1966 population was included as an additional measure of country size, defining the augmented gravity model ${ }^{6}$. This model is generally estimated in a log linear form which provides elasticity of bilateral trade to income (GDP: Yi , Yj ), country size (Population: POPi , POPj ) and distance (Dij).

\subsection{Variable selection and measure}

But according to related theory: The choice of traditional explanatory variables was based on the existing theoretical and empirical literature on the gravity model. In general, the gravity models claim that bilateral direct investment flows between any two economies are positively related to the size of the two economies and negatively related to the distance and Population. Distance between home and host markets, size of markets (GDP, Population) and the development level of countries have long been known to be major determinants of global trade flows. Starting by international trade literature, many empirical studies have tried to explain the determinants of FDI flows using different explanatory variables such as GDP or Population for measuring market size, and GDP per capita in measuring development level ${ }^{7}$. Since the dependent variable in the gravity model is bilateral direct investments flows between two countries, the product of GDP and the product of per capita GDP have been used as independent variables. We have added some additional independent variables in our model. The model is therefore "augmented" in the sense that several conditioning variables that may affect trade have been included. Thus the following gravity equation of trade for our regression analysis:

$\log ($ FDIij $)=\beta 0+\beta 1 \log ($ GDPi GDPj $)+\beta 2 \log ($ PCGDPi $\cdot$ PCGDPj $)+\beta 3 \log ($ Distanceij $)+$ $\beta 4($ Comlang _ off $)+\beta 4$ (Comborder) $+\beta 5$ (Comorg) $+\xi \mathrm{ij}$

where 
FDIij = Value of total trade between country i and country j;

GDPi $($ GDPj $)=$ Gross Domestic Product of country i (j);

PCGDPi $($ PCGDPj) = Per capita GDP of Country i (j);

Distanceij $=$ Distance between country i and country j;

Comlang_off = Common official language (dummy variable);

Colony = Colonial relationship (dummy variable);

$\xi \mathrm{ij}=$ is the regression error term.

As suggested by the economic theory, we expect positive signs for $\beta 1, \beta 2, \beta 4$ and a negative sign for $\beta 3$.

\subsection{Data sources}

The data of this study were obtained for a panel of countries over the period 2008-2016. The variables and their sources are summarised in Table1.

Table 1-Variables, definitions and data sources

\begin{tabular}{|c|c|}
\hline Variable & Defenition \\
\hline $\begin{array}{l}\text { Foreign Direct Investment } \\
\text { Flows. }\end{array}$ & $\begin{array}{l}\text { Source: National Bank of Kazakhstan } \\
\text { http://www.nationalbank.kz/ }\end{array}$ \\
\hline GDP & $\begin{array}{l}\text { Measured as logarithm. Data are presented in current US (\$). } \\
\text { Source: WorldBank }\end{array}$ \\
\hline $\begin{array}{l}\text { GDP per capita } \\
\text { Source: WorldBank }\end{array}$ & $\begin{array}{l}\text { Measured as logarithm. Data are presented in current US (\$). } \\
\text { Source: WorldBank }\end{array}$ \\
\hline Distance & Between financial capitals, measured in km.Source: www.yandex.ru/maps \\
\hline Language & $\begin{array}{l}\text { Countries official language Dummy variable }=1 \text { if the two countries have the } \\
\text { same language. } \quad \text { Source: CIA WorldFact. Online resourse. }\end{array}$ \\
\hline Organization & $\begin{array}{l}\text { Countries official language Dummy variable }=1 \text { if the two countries are the } \\
\text { members of the same organization (international, regional). } \\
\text { Source: Embassy of the Republic of Kazakhstan in the People's Republic of } \\
\text { China. www.mfa.kz Online resourse. }\end{array}$ \\
\hline Border & $\begin{array}{l}\text { Countries official language Dummy variable }=1 \text { if the two countries have the } \\
\text { same border. } \quad \text { Source: CIA WorldFact. Online resourse. }\end{array}$ \\
\hline
\end{tabular}

\section{Results and discussion}

Be using the NLS estimation method, together with the above model to analyze the which factors of Joint venture have influnce on FDI between two countries. The nonlinear regression 
model is a generalization of the linear regression model in which the conditional mean of the response variable is not a linear function of the parameters ${ }^{8}$. The empirical results are completed by Eviews 9. The column labeled "Coefficient” depicts the estimated coefficients. The "Std. Error" column reports the estimated standard errors of the coefficient estimates. The standard errors measure the statistical reliability of the coefficient estimates - the larger the standard errors, the more statistical noise in the estimates. The t-statistic, which is computed as the ratio of an estimated coefficient to its standard error, is used to test the hypothesis that a coefficient is equal to zero. To interpret the t-statistic, you should examine the probability of observing the t-statistic given that the coefficient is equal to zero. This probability computation is described below. The last column of the output shows the probability of drawing a t-statistic (or a z-statistic) as extreme as the one actually observed, under the assumption that the errors are normally distributed, or that the estimated coefficients are asymptotically normally distributed. This probability is also known as the p-value or the marginal significance level. Given a p-value, if the hypothesis is accepted or rejected then the true coefficient is zero against a two-sided alternative that it differs from zero.

The empirical results of the model are shown in Table 2. Estimation of gravity equation gave signs of coefficients as predicted by the economic theory.

Result of basic gravity model revealed that Product of two countries' GDPs has positive and significant impact on FDI. Its coefficient is 0.200000 and is significant at one percent level of significance. Its coefficient can be interpreted as keeping all other variables constant, a 1 percent point increase in product of the GDPs will on average lead to increase the flow of FDI from China to Kazakhstan 0.200000 percent. The signs of the GDPs per capita are positive and significant, showing that high income countries present higher level of international investment flows. The value of its coefficient is estimated to be 1.7387 with a positive sign as was expected and can be interpreted as keeping all other variables constant, a 1 percent point increase in product of the per capita GDPs will on average lead to increase the level of international investment flows.

Distance variable is having negative sign with its coefficient value of -13.95000 and is found significant at one percent level of significance. Coefficient of the distance variable can be interpreted as keeping all other variables constant, a 1 percent point increase in distance will on average lead to decrease the level of FDI from China to Kazakhstan by -13.95000 percent. To account for the observed geographical concentration of FDI flows, other control variables, such as dummy variable indicating whether the host and source countries share, for example, 
a common border and being the members of the same organization in this case it is called common organizations, are also taken into account. The seminal contribution of several studies have led to a large number of papers that estimate border effects based on a gravity framework and show it significance ${ }^{9,10}$. They both have a positive coefficient respectively of 55.80000 as predicted by the model. This means that foreign direct investments flow more between countries that have common border and common organizations.

The dummies variables Comlang_off which are representing respectively the common official language resulted to be non significant. The simple meaning of the statistical insignificance implies that language is not affecting at the FDI flow between China and Kazakhstan in this case.

Table 2 - Empirical analysis

\begin{tabular}{|l|l|l|l|l|}
\hline Variable & Coefficient & Std. Error & t-Statistic & Prob. \\
\hline A & 1.268182 & 0.098613 & 12.860019 & 0.0000 \\
\hline Log GDPij & 0.200000 & 0.305505 & 0.654654 & 0.5370 \\
\hline Log PCGDPij & 0.000000 & 0.365148 & 0.000000 & 1.0000 \\
\hline Log Distanceij & -13.95000 & 1.084743 & -12.86019 & 0.0000 \\
\hline Comorg & 55.80000 & 4.338971 & 12.86019 & 0.0000 \\
\hline Comborder & 55.80000 & 4.338971 & 12.86019 & 0.0000 \\
\hline R-squared & 0.100000 & Mean dependent var & 51.11111 \\
\hline Adjusted R-squared & -0.200000 & S.D. dependent var & 0.333333 \\
\hline S.E. of regression & 0.365148 & Akaike info criterion & 1.084176 \\
\hline Sum squared resid & 0.800000 & Schwarz criterion & 1.149917 \\
\hline Log likelihood & -1.878790 & Hannan-Quinn criterion & 0.942306 \\
\hline Durbin-Watson stat & 2.600000 & \multicolumn{4}{l}{} \\
\hline
\end{tabular}

\section{Conclusions}

The paper analysed the factors affecting the joint ventures presence of Chinese companies in Kazakhstan's regions. The analysis was conducted with a recently compiled cross-sectional data set from the period of 2008 - 2016 and with different specifications of a gravity model. Also was confirmed institutional theory by empirical estimation, which was mentioned in introduction. For estimation was used LS estimation method, together with the above model to analyze which factors of Joint venture have influence on FDI between two countries. A model can be nonlinear in its parameters, nonlinear in its observed variables, or nonlinear in 
both its parameters and variables. Nonlinear in the parameters means that the mathematical relationship between the variables and parameters is not required to have a linear form that's why all zero observations were excluded. The results suggest that gross products of host regions and source countries, common border and being the members of the same organization in this case it is called common organizations are positively related to the number of joint ventures in a particular Kazakhstan's region. The distance between host regions and source countries is negatively related to the dependent variable. As for the resource abundance there is no evidence of an expected positive influence on the dependent variable. Regarding the general conclusions we argue that the gravity model approach can be successfully applied to regional distribution of inward FDI in Kazakhstan irrespectively of the use of a number of joint ventures as a proxy for FDI.

\section{Acknowledgements}

I would like to pay special thanks, warmth and appreciation to the persons below who made my research successful and assisted me at every point to cherish my goal. My Supervisor, professor Yongjian Zong, for his vital support and assistance. His encouragement made it possible to achieve the goal. All the faculty whose services turned my research a success. My Mom and Dad, family members and friends, without whom I was nothing; they not only assisted me financially but also extended their support morally and emotionally.

\section{References}

1. Davis, P. S. Desai, A. B. \& Francis, J. D., "Mode of international entry: An isomorphism perspective,” Journal of International Business Studies, 31:2 (2000) 239258.

2. Huang, Y., \& Sternquist, B., "Retailers' foreign market entry decisions: An institutional perspective”, International Business Review, 16(5) (2007) 613-629.

3. $X u, D . \&$ Shenkar, O., "Institutional Distance and Multinational Enterprise", Academy of Management Review, 27:4 (2002) 608-618.

4. Brouthers, K. D., "Institutional, cultural and transaction cost influences on entry mode choice and performance”, Journal of International Business Studies, 33:2 (2002) 203-221.

5. Anderson, J.E., “A Theoretical Foundation for the Gravity Equation.”, American Economic Review, 63 (1979) 106-116. 
6. Bergstrand J.H., "The Gravity Equation in International Trade: Come microeconomic Foundations and Empirical Evidence”, The Review of Economics and Statistics, 67 (1985) 474-481.

7. Anderson, J.E., “The Gravity Model”, Annual Review of Economics, 3 (2011) 133-160.

8. Chien-Fu Wu, “Asymptotic theory of nonlinear least squares estimation”, Ann. Stat., 9 (3) (1981) 501-513.

9. McCallum, J., "National Borders Matter: Canada-U.S. Regional Trade Patterns”, American Economic Review, 85:3 (1995) 615-623.

10. Anderson, J. E., E. van Wincoop, "Gravity with Gravitas: A Solution to the Border Puzzle,” American Economic Review, 93 (2003) 170-192.

11. URL: www.cia.gov

12. URL: www.mfa.kz (01.10.2017.)

13. URL: www.nationalbank.kz (01.10.2017.)

14. URL: www.data.worldbank.org (01.10.2017.) 